\title{
Smoke Stick Dosage Form
}

National Cancer Institute

\section{Source}

National Cancer Institute. Smoke Stick Dosage Form. NCI Thesaurus. Code C87536.

A pharmaceutical dosage form in the shape of a stick; when lit, it delivers medicated smoke. 